Pesq. Vet. Bras. 28(1):70-76, janeiro 2008

\title{
Transmission of porcine circovirus 2 (PCV2) by semen and viral distribution in different piglet tissues ${ }^{1}$
}

\author{
Danielle Gava², Eraldo L. Zanella ${ }^{3}$, Nelson Morés ${ }^{4}$ and Janice R. \\ Ciacci-Zanella ${ }^{5^{*}}$
}

\begin{abstract}
Gava D., Zanella E.L., Morés N. \& Ciacci-Zanella J.R. 2008. Transmission of porcine circovirus 2 (PCV2) by semen and viral distribution in different piglet tissues. Pesquisa Veterinária Brasileira 28(1):70-76. Laboratório de Virologia, Embrapa Suínos e Aves, BR 153 Km 110, Vila Tamanduá, Cx. Postal 21, Concórdia, SC 89700000, Brazil. E-mail: janice@ cnpsa.embrapa.br

Porcine circovirus infections are caused by the porcine circovirus 2 (PCV2). Among six different clinical manifestations involving respiratory, enteric, nervous and reproductive signs, the postweaning multisystemic wasting syndrome (PMWS) is the most important and studied disease. However, reproductive failures associated with PCV2 have been increasingly reported. Some studies have shown the possible contamination of sows by semen of PCV2 positive boars. In order to investigate the transmission of PCV2 by contaminated semen and its ability to infect the sow and piglets, 20 PCV2 negative sows were inseminated, 10 with negative boar semen and 10 with previously nested-PCR tested positive boar semen. The sows were weekly monitored and blood samples were collected. Based on the results, 4 out 20 sows were selected ( 1 sow was PCR negative and inseminated with a negative semen, 2 sows were PCR negative and inseminated with a positive semen and 1 sow was PCR negative and inseminated with a positive semen, but became PCR positive around the 30 days of pregnancy). After weaning, 12 male piglets, 3 of each sow, were selected and maintained under isolation. In order to investigate which organs harbored the virus, the young pigs were necropsied around 9 months of age. Samples of serum collected monthly were tested by immunocitochemistry (ICC), and all 12 pigs serum converted. Samples of lymphoid, systemic and reproductive organs were analyzed by nested-PCR and immunohistochemistry (IHC). Evaluation of the samples by nested-PCR, revealed that several tissues were positive in 10 of 12 pigs, mainly the lymph nodes, bone marrow and spleen. Various samples were positive by IHC in 8 of 12 piglets, being the lymph nodes, tonsils and bulbourethral glands the most frequently positive. Thus, the results of testing different samples, in the 3 tests (ICC, nested-PCR and IHC) were complementary. These results show that PCV2 transmission through semen to the sows and piglets may occur and may also represent a potential risk for the herd.
\end{abstract}

TERMS: Swine, PCV2, semen, transmission, immunohistochemistry, PCR.

\footnotetext{
${ }^{1}$ Received on February 6, 2007.

Accepted for publication on November 22, 2007.

${ }^{2}$ Mestrado em Ciências Veterinárias, Centro de Ciências Agroveterinárias (CAV), Universidade do Estado de Santa Catarina (UDESC), Lages, SC 88520-000, Brazil. E-mail: daniellegava@gmail.com

${ }^{3}$ Faculdade de Agronomia e Medicina Veterinária, Universidade de Passo Fundo, Bairro São José, Cx. Postal 611, Passo Fundo, RS 99001970, Brazil.

${ }^{4}$ Laboratório de Patologia, Embrapa Suínos e Aves, C.P. 21, Concórdia, SC 89700-000, Brazil.

${ }^{5}$ Laboratório de Virologia, Embrapa Suínos e Aves, Concórdia, SC. ${ }^{*}$ Corresponding author: janice@ cnpsa.embrapa.br
}

RESUMO.- [Transmissão do circovirus suíno 2 (PCV2) pelo sêmen e distribuição do vírus nos tecidos da leitegada.] A circovirose suína é causada pelo circovirus suíno 2 (PCV-2). Dentre seis diferentes manifestações clínicas envolvendo sinais respiratórios, entéricos, nervosos e reprodutivos, a síndrome multissistêmica do definhamento do suíno (SMDS) é a doença mais importante e estudada. Todavia, relatos sobre falhas reprodutivas associadas ao PCV2 tem aumentado. Alguns estudos mostraram a possibilidade de contaminação das fêmeas pelo sêmen de machos positivos para PCV2. Com o objetivo de verificar a 
transmissão via sêmen de PCV2 e sua capacidade infecciosa para a fêmea e para a progênie, 20 fêmeas negativas para PCV2 foram inseminadas, 10 com sêmen de macho negativo e 10 com sêmen de macho positivo, testados previamente para PCV2 por um nested-PCR. As 20 fêmeas foram acompanhadas clinicamente e amostras de sangue foram coletadas. Baseado no resultado, quatro fêmeas das 20 foram selecionadas (uma fêmea PCR negativa inseminada com sêmen negativo, duas fêmeas PCR negativas inseminadas com sêmen positivo e uma fêmea PCR negativa inseminada com sêmen positivo, mas que soroconverteu ao redor dos 30 dias de gestação). Após o desmame, 12 leitões machos, três de cada fêmea, foram selecionados e mantidos em isolamento. Para verificar quais órgãos abrigam o PCV2, os suínos foram eutanasiados ao redor dos nove meses de idade. Amostras de sangue coletadas mensalmente foram testadas por imunocitoquímica (ICQ), e todos os 12 suínos soroconverteram. Amostras de órgãos linfóides, sistêmicos e reprodutivos foram avaliadas por nested-PCR e imunohistoquímica (IHQ). Ao avaliar as amostras por nested-PCR, vários tecidos foram positivos em 10 dos 12 suínos, sendo mais prevalentes linfonodos, medula óssea e baço. Ao avaliar as mesmas amostras por $\mathrm{IHQ}$, várias foram positivas em 8 dos 12 animais, sendo as mais prevalentes: linfonodos, tonsila e glândula bulbouretral. No geral, os resultados obtidos nas diferentes amostras nos três testes (ICQ, nested-PCR e IHQ) foram complementares entre si. Assim, estes resultados evidenciam que a transmissão do PCV2 pelo sêmen para as fêmeas e para a leitegada pode ocorrer, e que essa transmissão pode representar um potencial risco de infecção para o rebanho.

TERMOS DE INDEXAÇÃO: Suínos, PCV2, sêmen, transmissão, imunohistoquímica, PCR.

\section{INTRODUCTION}

Porcine circovirus infections are associated with porcine circovirus 2 (PCV2) and may result in six different clinical syndromes, among which the postweaning multisystemic wasting syndrome (PMWS) is the most important and studied clinical form. PCV2 also can be identified in swine affected with the epidemic form of porcine dermatitis and nephropathy syndrome (PDNS); as cause of reproductive failure or enteritis; as the co-factor of porcine respiratory complex; as cause of enteritis and associated with congenital tremors or nervous disease (Chae 2005). PMWS is a multifactorial disease associated with porcine circovirus 2 infection and was first described in Canada in 1991 (Harding 1996). The disease is currently present worldwide (Chae 2004).

PMWS was first diagnosed in Brazil in 2000 in Santa Catarina state (Ciacci-Zanella \& Morés 2000). However, retrospective studies indicated the presence of PCV2 and PMWS lesions since 1988 (Ciacci-Zanella et al. 2006). Subsequently, the disease has been described in several other states and in other countries; and both PCV1 and
PCV2 circulate within the Brazilian swine population (Castro et al. 2004).

PCV2 has been detected in nasal secretions, saliva, feces and serum (Shibata et al. 2003, Segalés et al. 2005), indicating horizontal transmission of the disease. Recently, vertical transmission associated with reproductive failure was reported (Pensaert et al. 2004, Maldonado et al. 2005, Park et al. 2005). Several studies point out for the possibility of alternative contagious routes, such as the boar semen (Larochelle et al. 2000, Kim et al. 2001), fomites, animal facilities and contact among infected pigs (Rose et al. 2003). In aborted fetuses and/or stillbirths and/or mummified fetuses, myocarditis, with macrophage and lymphocyte infiltration, fibrosis and myocardium degeneration with occasional presence of giant cells in addition to lymphocyte depletion in lymphoid tissues are observed (Allan \& McNeilly 2006). This viral tropism decreases gradually after birth (Pensaert et al. 2004, Mikami et al. 2005). In addition, reproductive failure and PMWS seem to be the only two syndromes caused by PCV2 alone, without the need of additional cofactors (Allan \& McNeilly 2006). In addition, some reports have shown the possibility of contamination of sows by semen of PCV2 positive boars (Pensaert et al. 2004, Maldonado et al. 2005, Mikami et al. 2005, Park et al. 2005 ).

The objectives of this work were to investigate the transmission of PCV2 by semen from naturally infected boars and its ability to infect the inseminated sows and their piglets. Male piglets born to inseminated sows were selected and studied till sexually mature, and the distribution of PCV2 antigens and DNA was investigated in their tissues.

\section{MATERIALS AND METHODS}

Experimental design. The pigs used in this study were of the synthetic genetic line MS60 (boars) and Landrace (sows). All animals were serologically negative for Aujezsky's disease virus and porcine parvovirus. Semen samples of boars from four Artificial Insemination Centers (AIC) in Brazil were collected, processed and analyzed by nested-PCR for PCV2 DNA (CiacciZanella et al. 2003, Ciacci-Zanella et al. data not shown). Following the test, four boars were selected, one positive $(A)$ and three negative (B1, B2 and B3) for PCV2 DNA. Semen from these boars was collected and tested by nested-PCR in a weekly basis for a two month period. Twenty PCV2 negative sows were inseminated, 10 with semen from negative boars (B1, B2 and B3) and 10 with semen from the positive boar (A). Sows were kept in isolated facilities of a PCV2-free herd. After the insemination, the 20 sows were clinically monitored and blood samples were collected and tested by nested-PCR fortnightly for the entire gestation period. Based on results of the nestedPCR, four sows (C, D, E, F) were selected; one sow (C) was $P C R$ negative and inseminated with negative semen, three sows (D, E, F) were PCR negative and inseminated with PCV2 positive semen. Five days before the insemination, blood from boars and sows, and semen from boars were collected for detection of PCV2 DNA by nested-PCR. Those samplings were performed four times on sows at 15, 30 and 45 days of pregnancy and one week after farrowing. 
After the weaning at 21 days of age, 12 male pigs (1D, 2D, $3 \mathrm{D}, 4 \mathrm{C}, 5 \mathrm{C}, 6 \mathrm{C}, 7 \mathrm{E}, 8 \mathrm{E}, 9 \mathrm{E}, 10 \mathrm{~F}, 11 \mathrm{~F}, 12 \mathrm{~F})$, three of each sow, were randomly selected and isolated. Nine of those (1D, 2D, 3D, 7E, 8E, 9E, 10F, 11F, 12F) were from litters of negative mothers $(D, E, F)$ and positive father $(A)$ and the other three $(4 \mathrm{C}, 5 \mathrm{C}, 6 \mathrm{C})$ were born to negative mother $(\mathrm{C})$ and father $(\mathrm{B} 1)$. The animals were placed in separated rooms per litter, were fed and examined twice a day. Serum samples were collected monthly and tested by immunocitochemistry (ICC) for PCV2 antibodies and nested-PCR. After sexual maturity (around six months of age), semen samples were collected twice with one month of interval from each boar and tested by nested-PCR.

At nine months of age, the boars were euthanized and a complete necropsy was performed. Samples of lymphoid tissues (tonsils, spleen, bone marrow, lymph nodes) trachea, heart, lungs, liver, pancreas stomach, intestines, kidneys and reproductive organs (ureters, bladder, penis, testicles, epididymis, prostate, bulbourethral glands, seminal vesicle, deferent duct) were collected and fixed in $10 \%$ buffered formalin or frozen for subsequent analysis by histopathology and $\mathrm{IHC}$, nested-PCR respectively.

Histopathology. Samples of tissues were embedded in paraffin, sectioned at $4 \mu \mathrm{m}$ and stained with hematoxylin and eosin (HE) for light microscopical examination (Luna 1968).

Immunocitochemistry. For serological examination, ICC was performed in ST cells (swine testicle cells, ATCC - CRL 1746) negative for PCV2, as described by Ciacci-Zanella \& Morés (2003). One-half of the plate (columns 1-6) were seeded with cells infected with PCV2 and the other half served as uninfected negative controls. Supernatant of culture medium was removed 12 and 24 hours following seeding the cells. The monolayer of cells were washed with PBS, fixed with methanol for $1 \mathrm{~min}$, frozen at $-20^{\circ} \mathrm{C}$ and analyzed by ICC. After fixation, cells were washed with distilled water and blocked with 30 volumes of $\mathrm{H}_{2} \mathrm{O}_{2} 1 \%$ in distilled water for $10 \mathrm{~min}$ at $37^{\circ} \mathrm{C}$. Following this treatment, the cells were washed three times for 5 min with TBS $0.05 \%$ Tween 20 and blocked with normal rabbit serum $10 \%$, for $1 \mathrm{~h}$ at $37^{\circ} \mathrm{C}$. After triple washing with TBS $0.05 \%$ Tween 20 , microplates were incubated with primary porcine serum (from those 12 pigs) in triplicates at 1:100 dilution overnight at $4{ }^{\circ} \mathrm{C}$. Cultures were washed three times with TBS $0.05 \%$ Tween 20 for $5 \mathrm{~min}$ and immunostained with a 1:100 dilution of anti-pig conjugated with peroxidase (Sigma, A-7042) at $37^{\circ} \mathrm{C}$ for $1 \mathrm{~h}$. Cells were then washed with TBS $0.05 \%$ Tween 20 three times, incubated with AEC (3-amino 9-ethyl-carbazole hydrogen peroxide substrate) solution for $5 \mathrm{~min}$ at room temperature and protected from light, afterwards counterstained with Meyer's hematoxylin for $2 \mathrm{~min}$ (Gava et al. 2005b). A porcine polyclonal antibody anti-PCV2 (VRMD, Inc. 211-P-PCRV) was used as a positive control and the negative control procedures included the omission of primary serum (used TBS instead), in addition to uninfected ST cells. The cells were visualized at an inverted light microscope and serological results were classified as negative (-) or reagent (strongly positive +++ , moderate positive ++ . and weakly positive + ).

Nested-PCR. Total DNA was isolated from swine tissues after storage at $-80^{\circ} \mathrm{C}$. Tissues were minced, digested overnight at $55^{\circ} \mathrm{C}$ in $5 \mathrm{~mL}$ of TEN buffer per gram of tissue $(10 \mathrm{mM}$ Tris, $1 \mathrm{mM}$ EDTA, $100 \mathrm{mM} \mathrm{NaCl}$ ) containing $0,5 \%$ SDS and $0,1 \mathrm{mg}$ proteinase K. DNA was extracted twice with phenol: chloroform:isoamyl alcohol (25:24:1), precipitated with $10 \mathrm{M}$ ammonium acetate and cold $100 \%$ ethanol (twice the final volume) and kept at $-20^{\circ} \mathrm{C}$ for 2 hours. The DNA was washed in
$70 \%$ ethanol, air dried and resuspended in TE (10 mM Tris, 1 mM EDTA, pH 7.4) (Sambrook et al. 1989). The semen and serum samples of all piglets were processed as the same way as the organs.

Nested-PCR amplifications were carried out as described by Kim et al. (2001). The primers used were designed from conserved sequences among PCV2 isolates of ORF2, which codifies the capsid protein; two reactions were performed. The nested primers amplified a 225 bp fragment. Control DNA from the reference strain was included in each reaction. Gel electrophoresis was carried out in $1 \%$ agarose gel in TBE buffer, stained with ethidium bromide and photographed (Sambrook et al. 1989). Molecular weight marker of $100 \mathrm{bp}$ was included in the gel to verify fragment lengths.

Immunohistochemistry. Samples of tissues embedded in paraffin were sectioned at $4 \mu \mathrm{m}$, placed on slides (previously treated with $10 \%$ poly-L-lysine) and IHC was performed as described previously (Gava et al. 2005a). Controls for the analyses includes samples of lymph nodes collected from Specific Pathogen Free pigs (SPF) and from PMWS positive pigs, previously tested by HE and nested-PCR (Ciacci-Zanella \& Mores 2003, Ciacci-Zanella et al. 2006). Sections were deparaffinized in xylene and rehydrated in decreasing graded alcohol solutions (100, 96, 80 and $70 \%$ ). Washing procedures were performed at each step using TBS 0,05\% Tween 20. Antigenic recovery was performed with $1 \%$ trypsin for 10 min and endogenous peroxidase activity was quenched by incubation of $3 \% \mathrm{H}_{2} \mathrm{O}_{2}$ for $5 \mathrm{~min}$. After washing the cells briefly, they were incubated with primary polyclonal rabbit PCV2 antibody (1:2000 dilution in PBS, kindly provided by Dr. David Driemeier, University of Rio Grande do Sul, Brazil) for 90min at $37^{\circ} \mathrm{C}$. This antibody is specific for the ORF2 capsid protein of PCV2 and was produced by Veterinary Diagnostic Laboratory, Ames, lowa, USA. The detection was performed by incubation of the sections $30 \mathrm{~min}$ at $37^{\circ} \mathrm{C}$ with a biotin-conjugated secondary antibody diluted $1: 15$ and later were incubated at $30 \mathrm{~min}$ at $37^{\circ} \mathrm{C}$ with a streptavidin-peroxidase conjugate diluted 1:15, both from the ExtrAvidin Peroxidase Staining Kit ${ }^{\circledR}$ (Sigma E-8386). The slides were then incubated with DAB (3,3'-diaminobenzidina) (Vector, Peroxidase Substrat Kit DAB) solution for $5 \mathrm{~min}$ at room temperature, and counterstained with Harris's hematoxylin for $1 \mathrm{~min}$. Slides were mounted with a mounting medium and examined under light microscopy.

\section{RESULTS \\ Clinical signs, lesions and PCV2 detection}

All sows were negative for PCV2 DNA amplification from blood by nested-PCR in all samplings, except sow $\mathrm{E}$, which became positive around 30 days of pregnancy. This indicates that PCV2 present in the semen infected this sow. All boars remained healthy during the entire experiment, and the negative boars maintained negative through the processing of all samples. The boar selected as positive for PCV2 and used to inseminate the sows was positive in all sample collections. The sows farrowed normal litters with an average of 11 born live piglets per sow.

The semen and serum of all 12 young pigs selected from those litters were also negative by nested-PCR. A $225 \mathrm{bp}$ amplified product by nested-PCR was observed in DNA samples from diverse organs. However, pigs 1D and 
Table 1. Nested-PCR and immunohistochemistry (IHC) in tissues samples of pigs

\begin{tabular}{|c|c|c|c|c|c|c|c|c|c|c|c|c|c|c|}
\hline $\begin{array}{l}\text { Porcine } \\
\text { samples }\end{array}$ & Technique & $1 \mathrm{D}$ & $2 \mathrm{D}$ & $3 \mathrm{D}$ & $4 \mathrm{C}$ & $5 \mathrm{C}$ & $6 C$ & $7 \mathrm{E}$ & $8 \mathrm{E}$ & $9 \mathrm{E}$ & $10 \mathrm{~F}$ & $11 \mathrm{~F}$ & $12 \mathrm{~F}$ & Total \\
\hline \multirow[t]{2}{*}{ Penis } & PCR & $-a$ & - & - & - & - & + & - & - & - & + & - & - & $2 / 12$ \\
\hline & $\mathrm{IHC}$ & - & - & - & - & - & - & - & - & - & - & - & - & $0 / 12$ \\
\hline \multirow{2}{*}{ Testicles } & PCR & - & - & - & - & - & + & - & - & - & + & - & - & $2 / 12$ \\
\hline & $\mathrm{IHC}$ & - & - & - & - & - & - & - & - & - & - & + & - & $1 / 12$ \\
\hline \multirow[t]{2}{*}{ Epididymis } & PCR & - & - & - & - & - & + & - & + & - & + & + & - & $4 / 12$ \\
\hline & $\mathrm{IHC}$ & - & - & - & - & - & - & - & - & - & - & - & - & $0 / 12$ \\
\hline \multirow[t]{2}{*}{ Deferent duct } & PCR & - & - & - & - & - & - & - & - & - & - & - & - & $0 / 12$ \\
\hline & $\mathrm{IHC}$ & - & - & - & - & - & - & - & - & - & - & - & - & $0 / 12$ \\
\hline \multirow[t]{2}{*}{ Prostate P } & $\mathrm{CR}$ & - & - & - & - & - & + & - & - & - & + & - & - & $2 / 12$ \\
\hline & $\mathrm{IHC}$ & - & - & - & - & - & - & - & - & + & - & - & - & $1 / 12$ \\
\hline \multirow[t]{2}{*}{ Seminal vesicle } & PCR & - & - & - & - & - & + & - & - & - & + & - & - & $2 / 12$ \\
\hline & $\mathrm{IHC}$ & - & - & - & - & - & - & - & + & - & - & - & - & $1 / 12$ \\
\hline \multirow[t]{2}{*}{ Bulbourethral glands } & PCR & - & - & - & - & + & + & - & - & - & + & - & - & $3 / 12$ \\
\hline & $\mathrm{IHC}$ & - & + & - & + & - & - & - & + & - & + & + & - & $5 / 12$ \\
\hline \multirow[t]{2}{*}{ Ureters } & PCR & - & - & - & - & - & - & - & - & - & - & + & - & $1 / 12$ \\
\hline & $\mathrm{IHC}$ & - & - & - & - & - & - & - & - & - & - & - & - & $0 / 12$ \\
\hline \multirow[t]{2}{*}{ Bladder } & PCR & - & - & - & - & - & + & - & - & - & + & - & - & $2 / 12$ \\
\hline & $\mathrm{IHC}$ & - & - & - & - & - & - & - & - & - & - & - & - & $0 / 12$ \\
\hline \multirow[t]{2}{*}{ Lymph nodes } & PCR & - & + & + & + & + & + & + & + & - & + & + & + & $10 / 12$ \\
\hline & $\mathrm{IHC}$ & - & - & - & + & - & + & - & ++ & - & ++ & + & - & $5 / 12$ \\
\hline \multirow[t]{2}{*}{ Tonsils } & PCR & - & - & - & - & - & + & + & + & - & + & + & - & $5 / 12$ \\
\hline & $\mathrm{IHC}$ & - & + & - & + & - & - & + & - & + & + & - & - & $5 / 12$ \\
\hline \multirow[t]{2}{*}{ Trachea } & PCR & - & + & - & - & - & - & - & - & - & + & - & + & $3 / 12$ \\
\hline & $\mathrm{IHC}$ & - & - & - & - & - & - & - & - & - & - & - & - & $0 / 12$ \\
\hline \multirow[t]{2}{*}{ Bone marrow } & PCR & - & + & + & + & - & + & + & - & - & + & + & + & $8 / 12$ \\
\hline & $\mathrm{IHC}$ & - & - & - & - & - & - & - & - & - & - & - & - & $0 / 12$ \\
\hline \multirow[t]{2}{*}{ Lungs } & PCR & - & + & - & + & + & + & - & - & - & + & + & - & $6 / 12$ \\
\hline & $\mathrm{IHC}$ & - & - & - & - & - & - & - & - & + & + & - & - & $2 / 12$ \\
\hline \multirow[t]{2}{*}{ Heart } & PCR & - & - & - & - & + & + & - & + & - & + & + & - & $5 / 12$ \\
\hline & $\mathrm{IHC}$ & - & - & - & - & - & - & - & - & - & - & - & - & $0 / 12$ \\
\hline \multirow[t]{2}{*}{ Liver } & PCR & - & - & - & + & - & + & + & + & - & + & + & - & $6 / 12$ \\
\hline & $\mathrm{IHC}$ & - & - & - & - & - & - & - & + & + & - & - & - & $2 / 12$ \\
\hline \multirow[t]{2}{*}{ Pancreas } & PCR & - & - & - & - & - & - & - & - & - & - & - & - & $0 / 12$ \\
\hline & $\mathrm{IHC}$ & - & - & - & - & - & - & - & - & - & - & - & - & $0 / 12$ \\
\hline \multirow[t]{2}{*}{ Spleen } & PCR & - & + & - & + & - & + & - & + & - & + & + & + & $7 / 12$ \\
\hline & $\mathrm{IHC}$ & - & - & - & - & - & - & - & + & - & - & - & - & $1 / 12$ \\
\hline \multirow[t]{2}{*}{ Kidneys } & PCR & - & + & - & + & - & - & - & - & - & + & - & - & $3 / 12$ \\
\hline & $\mathrm{IHC}$ & - & - & - & - & - & + & - & + & + & - & - & - & $3 / 12$ \\
\hline \multirow[t]{2}{*}{ Intestines } & PCR & - & - & - & - & - & + & + & + & - & + & - & - & $4 / 12$ \\
\hline & $\mathrm{IHC}$ & - & - & - & + & - & - & - & - & - & + & - & - & $2 / 12$ \\
\hline Total & PCR & $0 / 20$ & $6 / 20$ & $2 / 20$ & $6 / 20$ & $4 / 20$ & $15 / 20$ & $5 / 20$ & $7 / 20$ & $0 / 20$ & $17 / 20$ & $9 / 20$ & $4 / 20$ & \\
\hline & $\mathrm{IHC}$ & $0 / 20$ & $2 / 20$ & $0 / 20$ & $4 / 20$ & $0 / 20$ & $2 / 20$ & $1 / 20$ & $6 / 20$ & $5 / 20$ & $5 / 20$ & $3 / 20$ & $0 / 20$ & \\
\hline
\end{tabular}

a - Negative reaction, + Positive reaction (nested-PCR), + Weak positive reaction $(\mathrm{IHC}),++$ Moderate positive reaction (IHC).

9E were negative in all samples. The results are presented in Table 1. Tissue samples of reproductive system such as penis, epididymis, testicles, prostate, seminal vesicle, bladder, ureters, bulbourethral glands resulted positive. Other organs, such as tonsils, spleen, bone marrow, lymph nodes, trachea, heart, lungs, liver, intestines and kidneys were also positive in several animals. However, mostly frequently, samples of lymph nodes (10/12), bone marrow $(8 / 12)$, and spleen $(7 / 12)$ resulted positive. No detection of PCV2 DNA was possible in any of the pancreas and deferent duct samples. Fig.1 represents a nested-PCR from DNA extracted from organs of pig 10F.

Samples of all pigs were analyzed by $\mathrm{HE}$, but only the animal $8 \mathrm{E}$ presented discrete lesions. The lymph node presented hystiocitic infiltrate at central-follicular region and lymphoid follicles presented a lymphoblastic reduction.

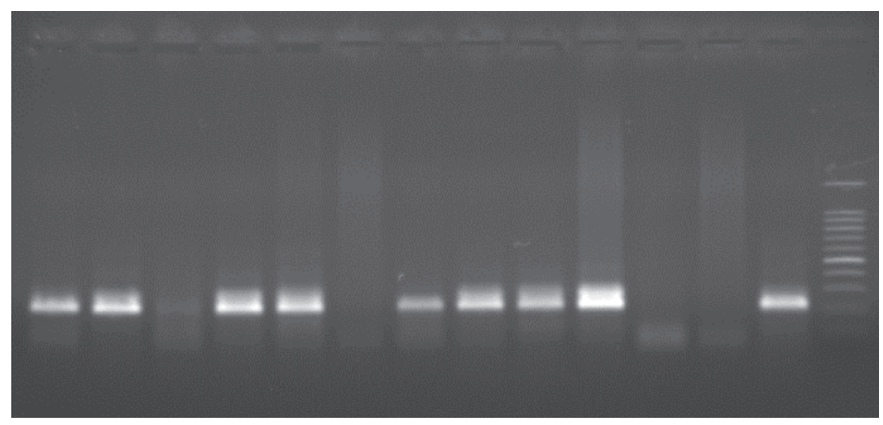

Fig.1. Nested-PCR of DNA samples extracted from organs of pig 10F. 1: Penis. 2: Testicle. 3: Epididymis. 4: Prostate. 5: bulbourethral gland. 6: Muscle of bulbourethral gland. 7: Parotid lymph nodes. 8: Lungs. 9: Liver. 10: Kidney. 11: Pancreas. 12: Negative Control. 13: Positive Control. 14: Molecular Weight Marker $100 \mathrm{pb}$. 

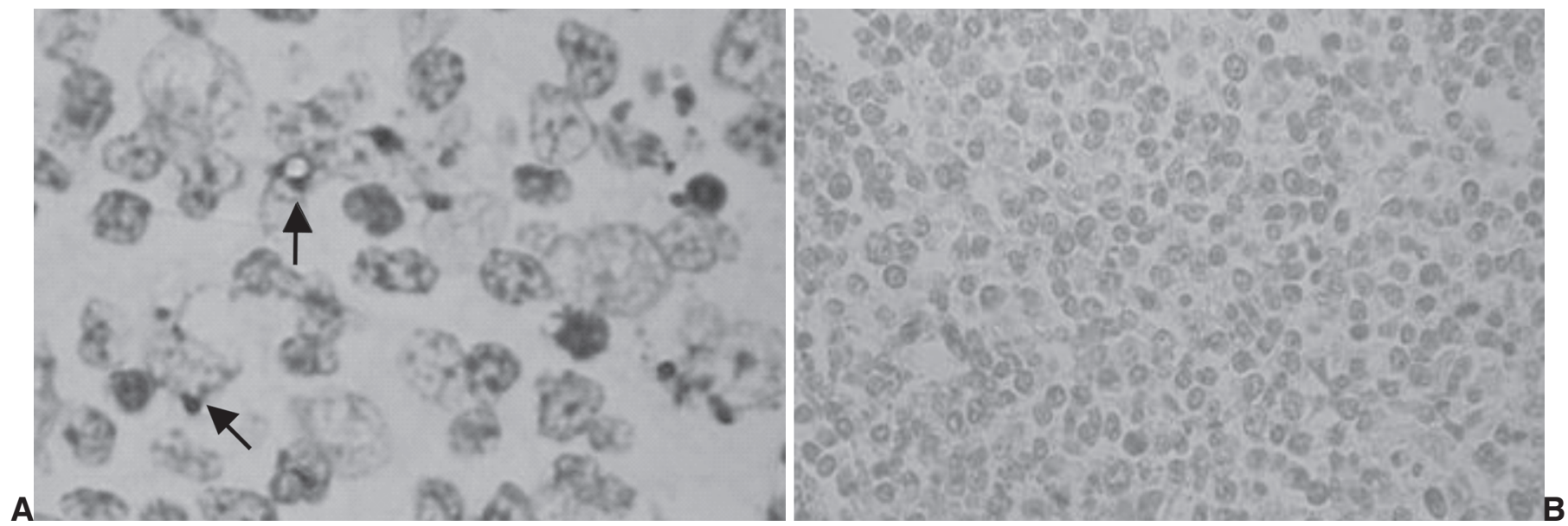

Fig.2. Immunohistochemistry reaction (IHC). A. Positive lymph node, DAB staining surround cellular membrane (arrows), obj.100x. B. Negative lymph node, no staining, obj.50x.

In addition to those lesions, a discrete mononuclear infiltration was observed in the heart surrounding blood vessels.

IHC analysis resulted positive on several tested samples however the intensity varied from weakly positive to moderate positive, but, pigs $1 \mathrm{D}, 3 \mathrm{D}, 5 \mathrm{C}$ and $12 \mathrm{~F}$ were negative in all tested samples (Fig.2A,B). Results are presented on Table 1. Tissue samples of bulbourethral glands (5/12), lymph nodes (5/12) and tonsils (5/12) were the organs in which PCV2 was detected most frequently, followed by kidneys $(3 / 12)$, lungs $(2 / 12)$, liver $(2 / 12)$, intestine (2/12) and finally testicles (1/12), prostate (1/12), seminal vesicle (1/12) and spleen (1/12). All other organs were negative. The fact of the pigs are clinically healthy, without clinical signs neither PMWS lesions, may be explained by the scarce presence of antigen.

\section{Serological evaluation}

All 12 serum samples were analyzed in duplicates by ICC and reacted positively, but with variable titers. Four of those were strongly positive (1D, 7E, 9E, 10F), three moderate positive $(3 \mathrm{D}, 8 \mathrm{E}, 12 \mathrm{~F})$ and five were weakly positive (2D, 4C, 5C, 6C, 11F). Negative controls did not react and positive control was graded as strong positive. These results indicate that all pigs were exposed to PCV2 at any time of their development.

\section{DISCUSSION AND CONCLUSIONS}

Herein the transmission of PCV2 by naturally contaminated swine semen and its ability to infect the sows and their piglets was studied. Twelve young male pigs were randomly selected, isolated and examined till sexually mature. Additionally, these selected male pigs were necropsied and their organs were analyzed by nested-PCR and IHQ in order to detect PCV2 DNA and antigens. Analyzing the results from the different tests used in this work, only pig 1D was negative in all samples, by both nested-PCR and by IHC. However, the pig 10F was the animal which presented the most numerous positive samples in both tests. Samples from pig $8 \mathrm{E}$, which presented microscopic lesions characteristic of PCV2 infection also resulted positive by nested-PCR and by IHC. Thus, in mostly of the tissues tested, the results by IHC and nested-PCR were in agreement.

According to Magar et al. (2000), PCV2 may be isolated without any clinical signs or evident lesions, suggesting the occurrence of subclinical infections and/or differences in virulence. Indeed, this variation of preference of PCV2 for some organs may be related to host susceptibility and/ or other co-factors. Although PCR is fast, sensitive and specific, is does not allow to identify the location of PCV2 in tissues or cells, neither the differentiation between PCV2 subclinically or clinically infected pigs (Brunborg et al. 2004). Liu et al. (2000) showed that levels of PCV2 DNA present on PMWS affected pigs are significantly higher than those in apparently healthy animals. This observation suggests that a minimal amount of PCV2 is necessary to produce disease. Herein, the performed tests did not evaluate quantitatively PCV2 in those male organs. However, it was possible to observe by IHC, small amounts of PCV2 antigens in some organs. The positive PCR results, including pigs $4 \mathrm{C}, 5 \mathrm{C}$ and $6 \mathrm{C}$ (litter of negative mother and father), indicate that the all pigs were exposed to PCV2 at any time of their development. Probably due to the absence of co-factors, or even low viral load, these animals did not develop the disease (Meerts et al. 2005).

The fact of some tissues resulted positive by nestedPCR in the absence of histological lesions or viral antigens IHC may indicate that the PCV2 DNA may be present in the sample without the disease manifestation (Gava et al. $2005 \mathrm{c}$,d). However, the presence of antibodies against PCV2 in clinically healthy animals indicate that, although PCV2 is essential to cause PMWS, it may not be sufficient to produce clinical signs, as demonstrated by others (Krakowka et al. 2005).

The results presented here by different techniques agree to those described by Quintana et al. (2001), Chianini et al. (2003) and Krakowka et al. (2005). These authors 
observed that the severity and distribution of the histopathological lesions are straightly related with the scores attributed to the $\mathrm{IHC}$ and to the amount of virus present in each organ. Similarly, the stage of the illness reflects the presence or absence of specific lesions (Rosell et al. 1999, Chae 2004, Segalés \& Domingo 2002, Segalés et al. 2004). However, it is also possible to find PCV2 antigen or nucleic acid in cells of clinically healthy animals, and in that case, the amount of virus and the degree of lesions are very low or negative.

According to Krakowka et al. (2005), piglets are usually infected with PCV2 after 4 to 6 weeks of age, due to decline of maternal antibodies. Following an experimental infection, PCV2 specific antibodies are detected at 10 to 14 days post-infection (dpi), but neutralizing antibodies are detected after 28 dpi (Meerts et al. 2005). ICC is not a serum-neutralization test, thus is able to detect PCV2 antibodies without distinction of neutralizing antibodies or not. Then, the presence of high antibody titers at ICC can not be taken as an indicator of protective immunity. Instead, the presence of antigens in tissues suggests that those antibodies were not protective. Krakowka et al. (2002), verified that infectious PCV2 may co-exist with high antibodies titers in the host, resulting in a high production of immunocomplexes during the infection process.

This is the first study of vertical transmission of PCV2 to negative sows and litters through naturally contaminated semen. In addition, this study followed up male piglets until they reached sexual maturity. These studies are cumbersome and lengthy. Herein, the PCV2 detection was not quantitative but by $\mathrm{IHC}$ analysis it was possible to observe small amounts of specific viral antigen in infected cells, especially on the male's reproductive tract. A similar study is underway, yet it is becoming very difficult to find negative sows to be inseminated with PCV2 contaminated semen due to the high dissemination of PCV2 among Brazilian herds.

In conclusion, this work showed amplification of DNA of PCV2 by nested-PCR from several organs of male pigs (fathered by PCV2 positive boar semen). The serological tests carried out by ICC allowed the detection of antibodies anti PCV2, similarly, the IHC also was capable to detect the antigen in diverse organs. By these reasons, the gross and histopathological lesions should be associated among themselves and with the detection of PCV2 antigen or DNA, in order to determine the final diagnosis of the disease. The association of nested-PCR and IHC tests showed that the PCV2 is located in lymphoid, systemic and also the male reproductive organs, which may represent a possible source of contamination. Furthermore, these results indicate that vertical transmission of PCV2 by naturally contaminated semen, through artificial insemination, may occur and thus represents a risk for infection of PCV2 negative herds.

Acknowlegements.- To Embrapa (03.04.3.38), CNPq (Edital Universal) and CAPES, for financial support.

\section{REFERENCES}

Allan G.M. \& McNeilly F. 2006. PMWS/PCVD, Diagnosis, disease and control: what do we know? Proc.19th Int. Pig Vet. Soc. Congr., Copenhagen, p.1-9.

Brunborg I.M., Moldal T. \& Jonassen C.M. 2004. Quantitation of porcine circovirus type 2 isolated from serum/plasma and tissue samples of healthy pigs and pigs with postweaning multisystemic wasting syndrome using a TaqMan-based real-time PCR. J. Virol. Methods 122(2):171-178.

Castro A.M.M.G., Cortez A., Ruiz V.L.A., Leomil H., Moreno A.M., Doto D.S. \& Richtzenhain L.J. 2004. Detection and differentiation of porcine circovirus in Brazilian pigs. Vet. Rec. 154(26):728-729.

Chae C. 2004. Postweaning multisystemic wasting syndrome: a review of aetiology, diagnosis and pathology. Vet. J. 168(1):41-49.

Chae C. 2005. A review of porcine circovirus 2-associated syndromes and diseases. Vet. J. 169(3):326-336.

Chianini F., Majo N., Segalés J., Dominguez J. \& Domingo M. 2003. Immunohistochemical characterization of PCV-2 associate lesions in lymphoid and non-lymphoid tissues of pigs with natural postweaning multisystemic wasting syndrome (PMWS). Vet. Immunol. Immunopathol. 94(1,2):63-75.

Ciacci-Zanella J.R. \& Mores N. 2000. Síndrome multissistêmica do definhamento do leitão desmamado (SMDLD) causada pelo circovirus suíno. Memoria Congr. Mercosur Prod. Porcina, Buenos Aires, p.16.

Ciacci-Zanella J.R. \& Mores N. 2003. Diagnosis of post-weaning multisystemic wasting syndrome in pigs in Brazil caused by porcine circovirus type 2. Arq. Bras. Med. Vet. Zootec. 55(5):522-527.

Ciacci-Zanella J.R., Bassi S.S., Ascoli K., Dahmer A. \& Zanella E.L. 2003. Detecção de circovirus suíno tipo 2 (PCV2) em sêmen de suínos. Anais $11^{\circ}$ Congr. Bras. Vet. Especialistas em Suínos, Goiânia, p.97-98.

Ciacci-Zanella J.R., Mores N., Simon N.L., Oliveira S.R. \& Gava D. 2006. Identificação de circovirus suino tipo 2 por reação em cadeia da polimerase e por imunoistoquímica em tecidos suínos arquivados desde 1988 no Brasil. Ciência Rural, Santa Maria, 36(5):1480-1485.

Gava D., Morés N., Ciacci-Zanella J.R. \& Oliveira S.R. 2005a. Padronização de uma técnica de imunohistoquímica (IHQ) em cortes histológicos para detecção de Circovirus Suíno tipo 2 (PCV-2) utilizando anticorpo monoclonal. Anais $12^{\circ}$ Congr. Bras. Vet. Especialistas em Suínos, Fortaleza, p.113-114.

Gava D., Ciacci-Zanella J.R., Mores N. \& Simon N.L. 2005b. Utilização da técnica de Imunocitoquímica (ICQ) para detecção de anticorpos contra o Circovirus Suíno tipo 2 (PCV-2) em soro suíno. Anais $12^{\circ}$ Congr. Bras. Vet. Especialistas em Suínos, Fortaleza, p.115-116.

Gava D., Mores N., Ciacci-Zanella J.R., Simon N.L., Triques N.J. \& Oliveira S.R. 2005c. Estudo comparativo entre histopatologia, imunocitoquímica (ICQ) e imunohistoquímica (IHQ) em suínos infectados por circovírus suíno tipo 2 (PCV2). Anais $12^{\circ}$ Congr. Bras. Vet. Especialistas em Suínos, Fortaleza, p.119-120.

Gava D., Zanella J.R.C., Morés N., Simon N.L. \& Oliveira S.R. 2005d. Detection of porcine circovirus type 2 (PCV-2) in tissues by polimerase chain reaction (PCR) and by histopathology (HE) - a comparative study. Anais $16^{\circ}$ Encontro Nac. Virologia, Salvador, BA, p.99.

Harding J.C.S. 1996. Post-weaning multisystemic wasting syndrome: preliminary epidemiology and clinical findings. Proc. $21^{\text {st }}$ Western Canadian Assoc. Swine Practitioners, Quebec, p.21.

Kim J., Han D.U., Choi C. \& Chae C. 2001. Differentiation of porcine circovirus (PCV)-1 and PCV-2 in boar semen using a multiplex nested polymerase chain reaction. J. Virol. Methods 98(1):25-31.

Krakowka S., Ellis J.A., McNeilly F., Gilpin D., Meehan B., McCullough K. \& Allan G. 2002. Immunologic features of porcine circovirus type 2 infection. Viral Immunol. 15(4):567-582.

Krakowka S., Ellis J., McNeilly F., Waldner C. \& Allan G. 2005. Features of porcine circovirus-2 disease: correlations between lesions, amount 
and distribution of virus, and clinical outcome. J. Vet. Diagn. Invest. 17(3):213-222.

Larochelle R., Bielanski A., Müller P. \& Magar R. 2000. PCR detection and evidence of shedding of porcine circovirus type 2 in boar semen. J. Clin. Microbiol. 38(12):4629-4632.

Liu Q., Wang L., Willson P. \& Babiuk L.A. 2000. Quantitative, competitive $\mathrm{PCR}$ analysis of porcine circovirus DNA in serum from pigs with postweaning multisystemic wasting syndrome. J. Clin. Microbiol. 38(9):3474-3477.

Luna L.G. 1968. Manual of Histologic Staining Methods of the Armed Forces Institute of Pathology. $3^{\text {rd }}$ ed. McGraw Hill, New York. 260p.

Magar R., Larochelle R., Thibault S. \& Lamontagne L. 2000. Experimental transmission of porcine circovirus type 2 (PCV2) in weaned pigs: a sequential study. J. Comp. Pathol. 123(4):258-269.

Maldonado J., Segalés J., Martinez-Puig D., Calsamiglia M., Riera P., Domingo M. \& Artigas C. 2005. Identification of viral pathogens in aborted fetuses and stillborn piglets from cases of swine reproductive failure in Spain. Vet. J. 169(3):454-456.

Meerts P., Van Gucht S., Cox E., Vandebosch A. \& Nauwynck H.J. 2005. Correlation between type of adaptive immune response against porcine circovirus type 2 and level of virus replication. Viral Immunol. 18(2):333-341.

Mikami O., Nakajima H., Kawashima K., Yoshii M. \& Nakajima Y. 2005. Nonsuppurative myocarditis caused by porcine circovirus type 2 in a weak-born piglet. J. Vet. Med. Sci. 67(7):735-738.

Park J.S., Kim J., Ha Y., Jung K., Choi C., Lim J.K., Kim S.H. \& Chae C. 2005. Birth abnormalities in pregnant sows infected intranasally with porcine circovirus 2. J. Comp. Pathol. 132(2-3):139-144.

Pensaert M.B., Sanchez R.E., Ladekjaer-Mikkelsen A.S., Allan G.M. \& Nauwynck H.J. 2004. Viremia and effect of fetal infection with porcine viruses with special reference to porcine circovirus type 2 infection. Vet. Microbiol. 98(2):175-183.
Quintana J., Segalés J., Rosell C., Calsamiglia M., Rodríguez-Arrioja G.M., Chianini F., Folch J.M., Maldonado J., Canal M., Plana-Durán J. \& Domingo M. 2001. Clinical and pathological observations of pigs with postweaning multisystemic wasting syndrome. Vet. Rec. 149(12):357-361

Rose N., Larour G., Le Diguerher G., Eveno E., Jolly J.P., Blanchard P., Oger A., Le Dimna M., Jestin A. \& Madec F. 2003. Risk factors for porcine post-weaning multisystemic wasting syndrome (PMWS) in 149 French farrow-to-finish herds. Prev. Vet. Med. 61(3):209-225.

Rosell C., Segalés J., Plana-Duran J., Balasch M., Rodriguez-Arrioja G.M., Kennedy S., Allan G.M., McNeilly F., Latimer K.S. \& Domingo M. 1999. Pathological, immunohistochemical, and in situ hybridization studies of natural cases of post-weaning multisystemic wasting syndrome (PMWS) in pigs. J. Comp. Pathol. 120(1):59-78.

Sambrook J., Fritsch E.F. \& Maniatis T. 1989. Molecular Cloning: a laboratory manual. $2^{\text {nd }}$ ed. Cold Spring Harbor Laboratory Press, New York.

Segalés J. \& Domingo M. 2002. Postweaning multisystemic wasting syndrome (PMWS) in pigs. A review. Vet. Quart. 24(3):109-124.

Segalés J., Rosell C. \& Domingo M. 2004. Pathological findings associated with naturally acquired porcine circovirus type 2 associated disease. Vet. Microbiol. 98(2):137-149.

Segalés J., Calsamiglia M., Olvera A., Sibila M., Badiella L. \& Domingo M. 2005. Quantification of porcine circovirus type 2 (PCV2) DNA in serum and tonsillar, nasal, tracheo-bronchial, urinary and faecal swabs of pigs with and without postweaning multisystemic wasting syndrome (PMWS). Vet. Microbiol. 111(3-4):223-229.

Shibata I., Okuga Y., Yazawa S., Ono M., Sasaki T., Itagaki M., Nakajima N., Okabe Y. \& Hidejima I. 2003. PCR detection of porcine circovirus type 2 DNA in whole blood, serum, oropharyngeal swab, and faeces from experimentally infected pigs and field cases. J. Vet. Med. Sci. 65(3):405-408 